\title{
A Novel Electrochemical CuO-Nanostructure Platform for Simultaneous Determination of 6-thioguanine and 5-fluorouracil Anticancer Drugs
}

\author{
Masoud Fouladgar ${ }^{1}$ \\ ${ }^{1}$ Department of Biochemistry, Falavarjan Branch, Islamic Azad University, Isfahan, Iran. \\ * Corresponding author: E-mail: Fouladgar@iaufala.ac.ir; \\ Tel: +989131295016
}

Received: 01-23-2019

\begin{abstract}
Analysis of anticancer drugs is very important and necessary for the correct administration of them in the human body. Electrochemical behavior of 6-thioguanine (6-TG) has been studied using a carbon paste electrode modified by 1-ethyl-3-methylimidazolium tetrafluoroborate (ionic liquid) (1E3MIBF4) and $\mathrm{CuO}$ nanoparticles (CuO/1E3MIBF4/ $\mathrm{CPE}$ ). Using square wave voltammetry showed the linear relation between net anodic current and concentration of 6-TG in the range of $70 \mathrm{nmol} \mathrm{L}^{-1}$ to $520 \mu \mathrm{mol} \mathrm{L}^{-1} 6$-TG with the detection limit of $20 \mathrm{nmol} \mathrm{L}^{-1} 6$-TG. The proposed modified electrode had excellent repeatability ( $\mathrm{RSD}=1.31 \%, \mathrm{n}=5)$ and long term stability ( $2.9 \%$ deviation in 25 days). The diffusion coefficient of 6-TG on the $\mathrm{CuO} / 1 \mathrm{E} 3 \mathrm{MIBF} / \mathrm{CPE}$ was found to be $1.54 \times 10^{-5} \mathrm{~cm}^{2} \mathrm{~s}^{-1}$. The CuO/1E3MIBF4/ CPE was successfully applied for the determination of 6-TG in real samples. In addition, the anodic peaks of 6-TG and fluorouracil (5-FU) in their mixture can be well separated using $\mathrm{CuO} / 1 \mathrm{E} 3 \mathrm{MIBF} 4 / \mathrm{CPE}$ and simultaneous determination of them was studied.
\end{abstract}

Keywords: 6-Thioguanine; 5- Fluorouracil; $\mathrm{CuO}$ nanoparticles; 1-ethyl-3-methylimidazolium tetrafluoroborate; voltammetry

\section{Introduction}

6-Thioguanine (6-TG) is a common anticancer and antitumor drug which is an analogue of the physiological purines, guanine and hypoxanthine. In addition, thioguanine has been applied for treatment of hematological malignancies, psoriasis and inflammatory bowel disease, such as Crohn's disease. It has interaction with DNA and RNA and using it may have several side effects. Its main side effects are on the liver and it can cause hemotoxicity as well. ${ }^{1}$ Oral administrated of 6-TG is poorly absorbed and about $30 \%$ of administered dose being bioavailable. In hepatic metabolism of 6-TG, a methyl group is added to the sulfhydryl group of 6-TG. ${ }^{2}$

5-Fluorouracil (5-FU) is an antimetabolite agent same as 6-thioguanine that is being used for treatment of cancer. This group of drugs disrupts nucleic acid synthesis and is toxic to normal cells. It is a fluorinated pyrimidine and inhibits synthesis of DNA by blocking thymidylate synthetase. It is used in treatment of small tumors for which surgery is contraindicated. Particularly it is em- ployed for the treatment of metastatic carcinomas of the breast, gastrointestinal tract, head and neck, and pancreas. Administered 5-Fluorouracil undergoes hepatic metabolism and about $10 \%$ of administered dose excretes unchanged in urine. ${ }^{2}$ Both 6-TG and 5-FU are in the list of World Health Organization's List of Essential Medicines. ${ }^{3}$

Control of the adverse side effects of drugs and determination the pharmacokinetics properties are the important reasons to measurement the drugs in pharmaceutical samples and in biological samples too. In this regard many analytical methods have been reported to analysis drug samples including electrochemical methods. ${ }^{4,5}$ Many modified electrochemical sensors have been suggested for determination and studying interactions of 6-TG. Madueno et al. have been studied electrochemical oxidation of this anticancer drug (6-TG) including adsorption and phase formation on the mercury electrode. ${ }^{6}$ Wang et al. could measure 6-TG by modified gold electrode with DNA. Potassium ferricyanate was used as an electroactive indicator to probe the interaction between 6-TG and DNA. ${ }^{7}$ Ensafi et al. used the ability of 6-TG to form com- 
plex with $\mathrm{Cu}$ (II) and cathodic striping on the mercury electrode. ${ }^{8}$ Beitollahi et al. reported application of 2,7-bis (ferrocenyl ethyl)fluoren-9-one as a modifier of carbon paste electrode. They determined 6-TG based on electrocatalytic effect of modifier. ${ }^{9}$ Eksin et al. studied interaction between 6-TG and ss-DNA on the pencil graphite electrode and obtianed data confirmed interactions between 6-TG and ss-DNA. ${ }^{10}$ Beitollahi et al. reported determination of 6-TG and folic acid using amplified sensors with $\mathrm{ZnO}-\mathrm{CuO}$ nanoplates and 2-chlorobenzoyl ferrocene. ${ }^{11}$

To improve the analytical features of the electrochemical methods, applied electrodes have been modified with different materials. ${ }^{12-14}$ In recent years, nanomaterials have been widely used in electrochemical analysis methods. ${ }^{15-20}$ Electrochemical sensors amplified with conductive materials help to improving sensitivity of electroactive materials sensors and also increase the diversity of them. ${ }^{21-26}$ In between, nanomaterials with different and unique properties showed more attention for modification of electrochemical sensors. ${ }^{27-31}$ One of the effects of application of nanomaterials is due to the change in the active surface area of electrodes. ${ }^{32-34}$ This effect and some other effects that appear when the size of particles decreases to nanoscale, cause to improve performance of electrochemical methods. ${ }^{35}$ However, application of nanoparticles may have disadvantage effect on the electrochemical signals and increases background currents. Copper oxide nanoparticles are semiconductor metal that not only have special electrical and magnetic properties but also have great biological properties including effective antimicrobial action. Wide applications of $\mathrm{CuO}$ nanoparticles has caused significant advance in synthesis approaches of $\mathrm{CuO}$ nanoparticles. ${ }^{36}$ Zeta potential values of $\mathrm{CuO}$ nanoparticles are negative or positive depending on $\mathrm{pH}$ of solution and can effect adsorption of electroactive species and improve electrochemical signals. ${ }^{37}$

In addition, using electrically conducting liquids especially ionic liquids in the structure of paste electrodes, improves the sensitivity of the electrodes. ${ }^{38-46}$ 1-ethyl-3-methylimidazolium tetrafluoroborate is a room temperature ionic liquid that has suitable electrochemical stability for voltammetric aspects. It has wide voltage range of the electrochemical window, which allows electrochemical studies on various electroactive compounds. ${ }^{47,48}$

In this work, synthesized $\mathrm{CuO}$ nanoparticles and $1 \mathrm{E} 3 \mathrm{MIBF}_{4}$ were used for amplification of modified sensor. Composition of $\mathrm{CuO} / 1 \mathrm{E}_{3} \mathrm{MIBF}_{4} / \mathrm{CPE}$ was optimized and $\mathrm{CuO} / 1 \mathrm{E} \mathrm{MIBF}_{4} / \mathrm{CPE}$ was suggested to determine 6-TG in real samples. In addition, simultaneous determination of 6-TG and 5-FU was investigated using modified electrode.

\section{Experimental}

\section{1. Materials and Devices}

All chemical compounds (6-thioguanine, 5-fluorouracil, phosphoric acid, 1-ethyl-3-methylimidazolium tetrafluoroborate, copper(II) acetate, paraffin oil, sodium hydroxide and graphite powder) were purchased from Sigma-Aldrich Company in analytical grade and they were used as received without any further purification. Ultrapure water (18.2 $\mathrm{M} \Omega \mathrm{cm}$, Mili-Q) was used for preparation of solutions. Phosphate buffer solutions were prepared by mixing adequate amounts of $0.1 \mathrm{~mol} \mathrm{~L}^{-1}$ sodium dihydrogen phosphate and $0.1 \mathrm{~mol} \mathrm{~L}^{-1}$ sodium hydrogen phosphate solutions. To prepare 6-TG standard solution $\left(1 \times 10^{-3} \mathrm{~mol} \mathrm{~L}^{-1}\right)$, adequate amount of 6 -TG was dissolved in warm $\left(35-40{ }^{\circ} \mathrm{C}\right)$ 1:1 $(\mathrm{v} / \mathrm{v})$ water-ethanol solution.

Electrochemical measurements were executed by Autolab PGSTAT 101 potentiostat/galvanostat (Metrohm, Netherlands) in a conventional electrochemical cell (50 $\mathrm{ml})$. An $\mathrm{Ag} / \mathrm{AgCl}$ electrode and a platinum wire electrode were applied as reference electrode and counter electrode, respectively. $\mathrm{CuO} / 1 \mathrm{E}^{2} \mathrm{MIBF}_{4} / \mathrm{CPE}$ was used as working electrode.

\section{2. Real Sample Preparation}

To prepare the tablets sample, five tablets were exactly weighed. Then the tablets were grinded and were completely homogenized. Then a required amount of the powder was transferred to the $100 \mathrm{ml}$ beaker and about 80 $\mathrm{ml}$ of warm $\left(35-40^{\circ} \mathrm{C}\right) 1: 1(\mathrm{v} / \mathrm{v})$ water-ethanol solution was added. The mixture was stirred magnetically and ultrasonicated ( $15 \mathrm{~min})$ till the powder was dissolved. Afterward, the solution was filtered by filter paper and transferred to a flask and diluted to $100 \mathrm{ml}$ with water-ethanol solution. For electrochemical measurement, adequate amount of resultant solution was transfer to electrochemical cell containing $10 \mathrm{ml}$ of phosphate buffer solution $(\mathrm{pH}=7.0)$.

The spiked dextrose-saline solution was prepared by mixing dextrose-saline solution with the same volume of phosphate buffer solution $(\mathrm{pH}=7.0)$. Then $10 \mathrm{ml}$ of resultant solution was added to the electrochemical cell and adequate amount of standard solution of 6-TG was added.

\section{3. Nanoparticle Synthesis}

$200 \mathrm{ml}$ of $0.2 \mathrm{~mol} \mathrm{~L}^{-1}$ copper(II)acetate mixed with 2 $\mathrm{ml}$ acetic acid solution and mixture was heated until it came to boil. Then $30 \mathrm{ml}$ of $0.8 \mathrm{~mol} \mathrm{~L}^{-1} \mathrm{NaOH}$ were added to the mixture. The color of the solution changed from blue to black. Afterwards, the mixture was boiled for $2 \mathrm{~h}$. After cooling the mixture in the air, it was centrifuged into solid and water and the obtained solid was separated and washed.

\section{4. Fabrication of $\mathrm{CuO} / 1 \mathrm{E} \mathrm{MIBF}_{4} / \mathrm{CPE}$}

The composition of $\mathrm{CuO} / 1 \mathrm{E}_{3} \mathrm{MIBF}_{4} / \mathrm{CPE}$ was optimized and optimum composition contained 10\% $1 \mathrm{E}$ 
$3 \mathrm{MIBF}_{4}$ and $6 \%$ nanoparticles. Accordingly, a mixture including $10 \% 1 \mathrm{E}_{3} \mathrm{MIBF}_{4}$ as ionic liquid, $6 \% \mathrm{CuO}$ nanoparticles and $84 \%$ graphite powder was prepared. About $1 \mathrm{ml}$ of diethyl ether was added to the mixture and the mixture was mixed until a uniform mixture obtained. After vaporization of diethylether, a suitable amount of viscose paraffin was added to the mixture and components were mixed and the obtained paste was inserted into the glass tube in the presence of copper wire.

\section{5. Recommended Procedure}

Prepared modified electrode was polished with a white and clean paper. To measure blank signal, ten milliliters of buffer solution $(\mathrm{pH}=7.0)$ were transferred to the electrochemical cell. Then, the square wave voltammogram was recorded from 0.35 to $1.25 \mathrm{~V} \mathrm{~V} \mathrm{vs.} \mathrm{Ag} / \mathrm{AgCl}$ (Frequency $10 \mathrm{~Hz}$ ). Afterward, different amounts of standard solutions of 6-TG and/or 5-FU were added to the cell and square wave voltammograms were recorded again to get the analytical signal. The difference between the blank and the analytical signal was obtained as a net peak current. Calibration plot was constructed by plotting net currents $v s$. concentration of drugs.

\section{Results and Discussion}

\section{1. Investigation of Synthesized Nanoparticles}

Scanning electron microscopy (SEM) of synthesized nanoparticles confirmed synthesis of uniform spherical particles with nanoscale size (Figure 1.a). In addition, obtained Energy-dispersive X-ray (EDX) spectrum from synthesized nanoparticles confirmed the existence of only oxygen and copper in the composition of nanoparticles (Figure 1.b).

\section{2. $\mathrm{pH}$ effect}

According to the previous electrochemical reported papers for analysis of $6-\mathrm{TG}^{49}$ we guessed the $\mathrm{pH}$ dependent electro-oxidation mechanism for determination of 6-TG at a surface of electrode. Therefore, linear sweep voltammograms of 6-TG $\left(100 \mu \mathrm{mol} \mathrm{L}^{-1}\right)$ were recorded in the pHs range of 5-8. As can be seen in Figure 2 (inset), increasing $\mathrm{pH}$ of solution causes the shift of oxidation peak potential to negative potentials. The slope of plot of potential versus $\mathrm{pH}$ was $-61.2 \mathrm{mV} / \mathrm{pH}$, which is close to anticipated Nernstian value (Figure 2). Consequently, this indicates that the electro-oxidation of 6-TG occurred in the presence of equal value of proton and electron. The obtained result agrees with the suggested mechanism for electro-oxidation of 6-TG (Scheme 1). ${ }^{49}$

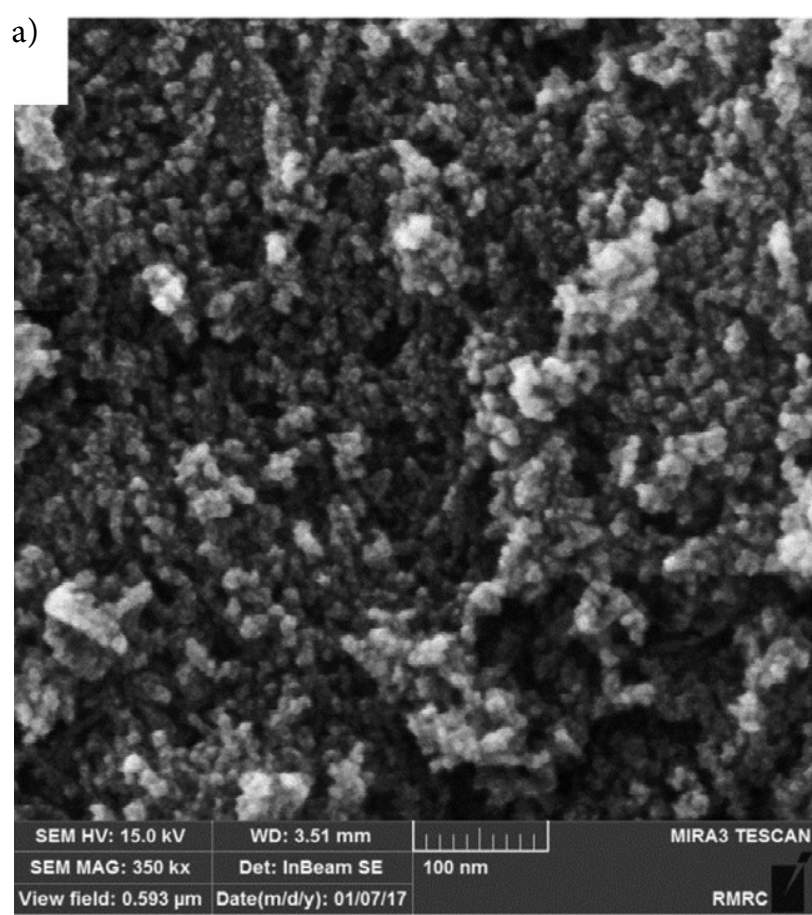

b)

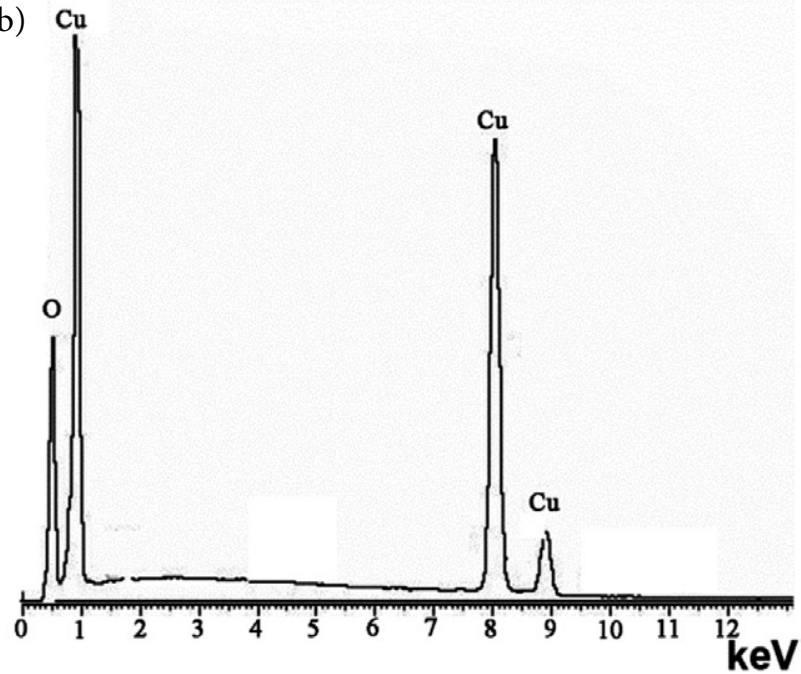

Figure 1. a) SEM image b) EDX spectrum of synthesized $\mathrm{CuO}$ nanoparticles

\section{3. Effect of Modification}

In this step, we investigated the synergic effect of modifiers on the 6-TG electro-oxidation signal by recording the linear sweep voltammograms 6-TG $\left(100 \mu \mathrm{mol} \mathrm{L}^{-1}\right)$ at a surface of $\mathrm{CuO} / 1 \mathrm{E}^{2} \mathrm{MIBF}_{4} / \mathrm{CPE}$ (curve a), $1 \mathrm{E}^{2} \mathrm{MIBF}_{4} /$ $\mathrm{CPE}$ (curve b), $\mathrm{CuO} / \mathrm{CPE}$ (curve c) and CPE (curve d). As can be seen in Figure 3, addition of $\mathrm{CuO}$ nanoparticles caused increasing oxidation current and shifting peak potential toward lower potentials. Addition of ionic liquid into the carbon paste had similar effects. Synergy between effects of addition of nanoparticles and ionic liquid caused to achieve maximum peak current and lower overpotential (Figure 3. a). In addition, the current density in- 


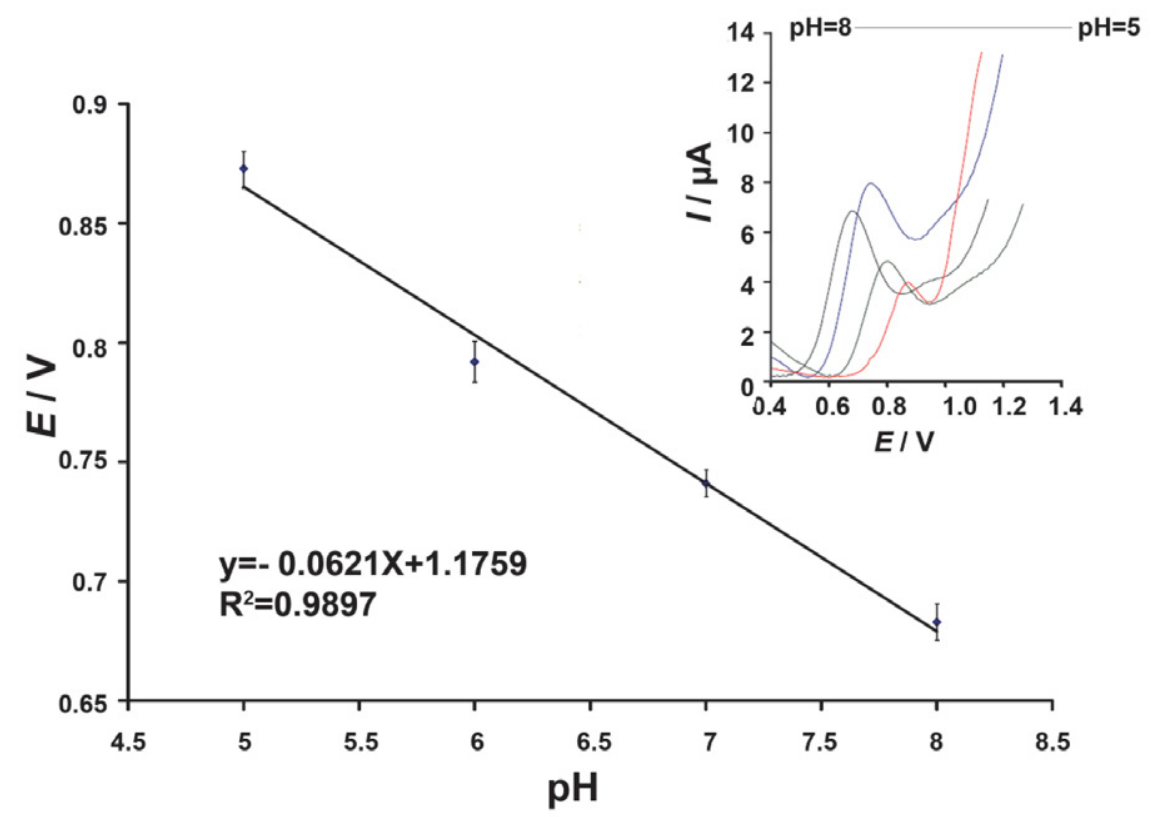

Figure 2. Plot of potential $v s$. $\mathrm{pH}$ for the electrooxidation of $100 \mu \mathrm{mol} \mathrm{L}^{-1} 6-\mathrm{TG}$ at $\mathrm{CuO} / 1 \mathrm{E} 3 \mathrm{MIBF}_{4} / \mathrm{CPE}$. Inset: Linear sweep voltammograms of 100 $\mu \mathrm{mol} \mathrm{L}{ }^{-1}$ 6-TG with different $\mathrm{pHs}$ ( scan rate $=100 \mathrm{mV} \mathrm{s}^{-1}$ ).
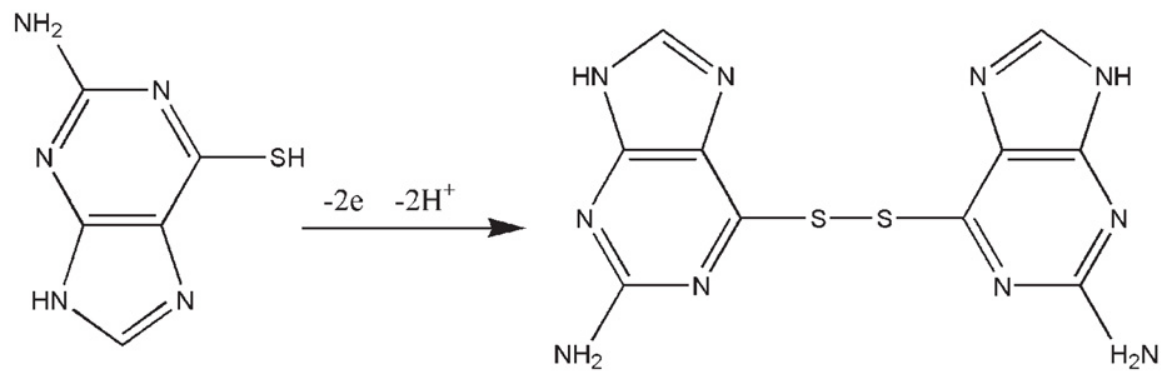

Scheme 1. Proposed mechanism for oxidation of 6-TG on the electrode.

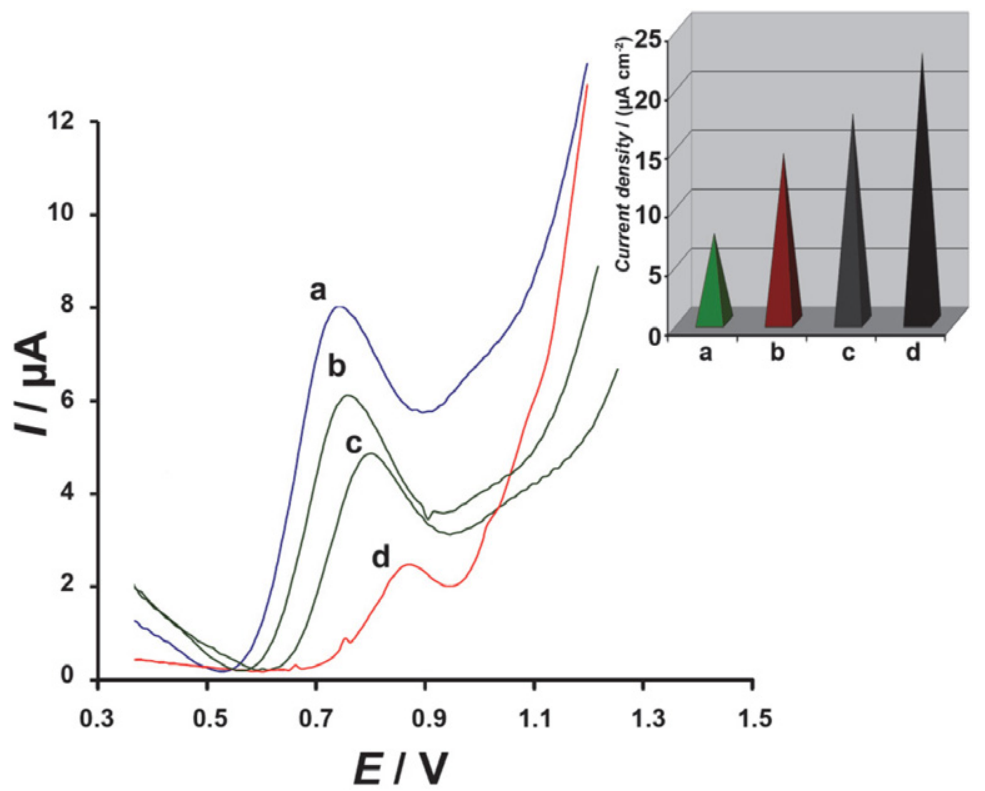

Figure 3. Linear sweep voltammograms of (a) $\mathrm{CuO} / 1 \mathrm{E} 3 \mathrm{MIBF}_{4} / \mathrm{CPE}$, (b) $1 \mathrm{E} 3 \mathrm{MIBF}_{4} / \mathrm{CPE}$, (c) $\mathrm{CuO} / \mathrm{CPE}$, and (d) $\mathrm{CPE}$ in the presence of $100 \mu \mathrm{mol}$ $\mathrm{L}^{-1} 6-\mathrm{TG}$ at $\mathrm{pH}$ 7.0. Inset: the current densities derived from voltammograms responses at same electrodes. 
creased by moving $\mathrm{CPE}$ to $\mathrm{CuO} / 1 \mathrm{E} 3 \mathrm{MIBF}_{4} / \mathrm{CPE}$ (Figure 3. inset).

These effects may be relative to the conductivity effect of $\mathrm{CuO}$ nanoparticles and $1 \mathrm{E}^{2} \mathrm{MIBF}_{4}$ at a surface $\mathrm{CPE}$. In addition, the active surface area of modified and non-modified electrodes $\mathrm{CuO} / 1 \mathrm{E}_{3} \mathrm{MIBF}_{4} / \mathrm{CPE}, 1 \mathrm{E} 3 \mathrm{MIBF}_{4}$ /CPE, $\mathrm{CuO} / \mathrm{CPE}$ and $\mathrm{CPE}$ was obtained based on the Randles-Sevcik equation (in the presence of $1 \mathrm{mM}$ $\left.\mathrm{K}_{4} \mathrm{Fe}(\mathrm{CN})_{6}\right){ }^{32}$ The active surface areas of $\mathrm{CPE}, \mathrm{CuO} / \mathrm{CPE}$, $1 \mathrm{E}^{2} \mathrm{MIBF}_{4} / \mathrm{CPE}$ and $\mathrm{CuO} / 1 \mathrm{E} 3 \mathrm{MIBF}_{4} / \mathrm{CPE}$ were calculated equals; $0.28,0.31,0.32$ and $0.33 \mathrm{~cm}^{2}$, respectively.

\section{4. Electrochemical Investigations}

Linear sweep voltammograms of 6-TG $(300 \mu \mathrm{mol}$ $\mathrm{L}^{-1}$ ) at $\mathrm{CuO} / 1 \mathrm{E}^{2} \mathrm{MIBF}_{4} / \mathrm{CPE}$ were recorded in the scan range between $10-100 \mathrm{mVs}^{-1}$ (Figure 4 -a insert). Linear relation between peak currents and square root of scan rates confirmed that the electrode process was controlled under the diffusion step. In addition, a kinetic limitation can be observed in this investigation due to shifted oxidation peak potential toward positive value. Also, the value of charge transfer coefficient $(\alpha)$ was obtained $\sim 0.8$ using slope of Tafel plot (Figure 4-b).

Chronoamperometry was also employed for investigation of 6-TG (300 and $500 \mu \mathrm{mol} \mathrm{L}^{-1}$ ) electro-oxidation at $\mathrm{CuO} / 1 \mathrm{E} \mathrm{MIBF}_{4} / \mathrm{CPE}$ by applying single potential step $800 \mathrm{mV}$ at $\mathrm{CuO} / 1 \mathrm{E} 3 \mathrm{MIBF}_{4} / \mathrm{CPE}$. From the slopes of plots of $I$ (current) versus $t^{-1 / 2}$ (Figure 5), the average of diffusion coefficient of 6-TG was found to be $1.54 \times 10^{-5}$ $\mathrm{cm}^{2} \mathrm{~s}^{-1}$ (Cottrell equation). Since electrode reaction is diffusion-controlled, anodic current is controlled by diffusion and hence depends on the diffusion coefficient. Modification of electrode causes increasing diffusion coefficient which in turn leads to increasing anodic current.
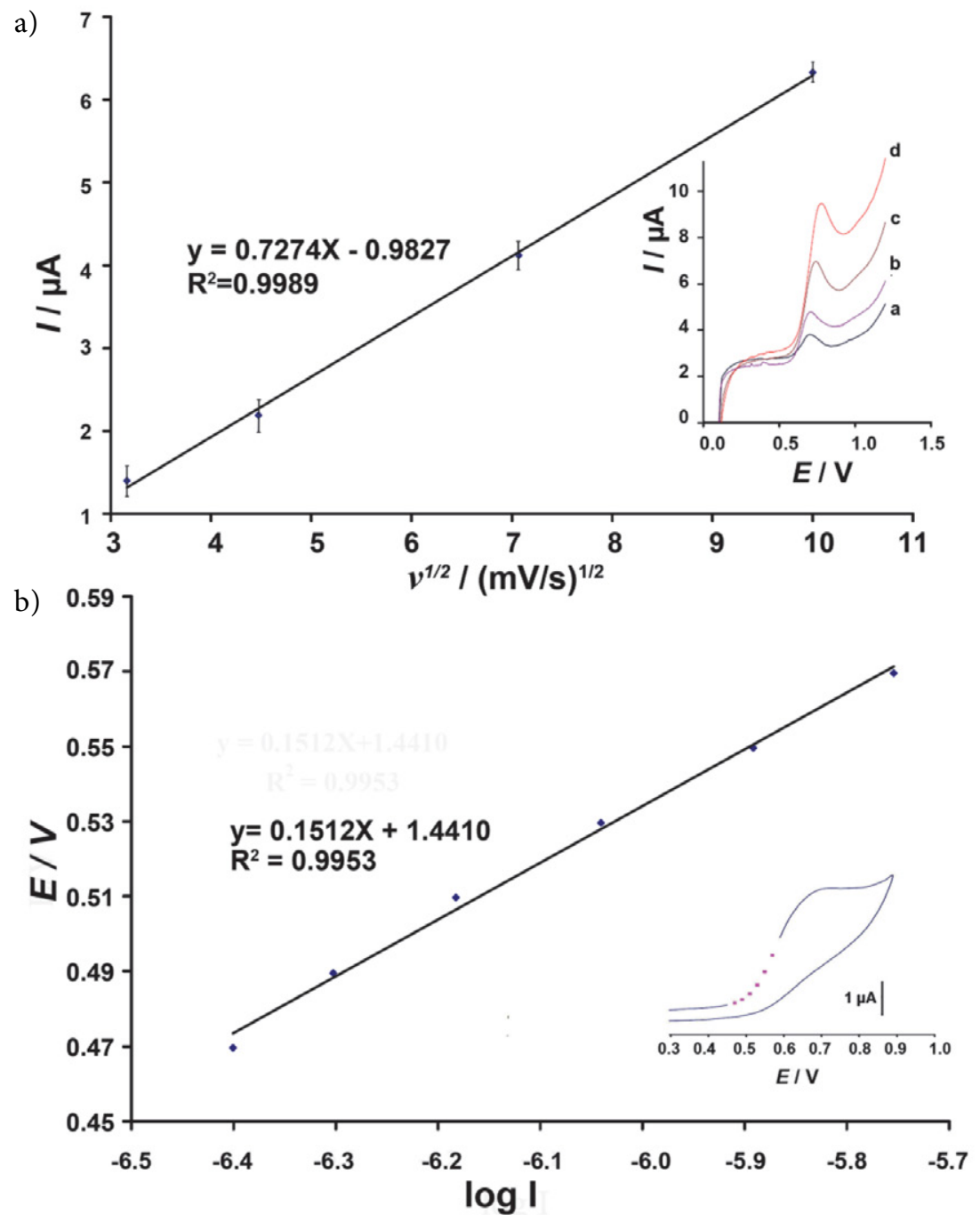

Figure 4. a) The Plot of $I_{p a} v s . v^{1 / 2}$ for electro-oxidation of $300 \mu \mathrm{mol} \mathrm{L}^{-1} 6-\mathrm{TG}(\mathrm{pH}=7.0)$. Insert; linear sweep voltammograms of $\mathrm{CuO}_{1} \mathrm{E}^{2} \mathrm{MIBF} /$ $\mathrm{CPE}$ containing $300 \mu \mathrm{mol} \mathrm{L}^{-1} 6$-TG at various scan rates; a-d correspond to 10, 20, 50 and $100 \mathrm{mVs}^{-1}$, respectively. b) Tafel plot for $300 \mu \mathrm{mol} \mathrm{L}-1$ (pH = 7.0) $6-\mathrm{TG}$ at $\mathrm{CuO} / 1 \mathrm{E} \mathrm{MIBF}_{4} / \mathrm{CPE}$. Inset: Corresponding cyclic voltammogram 


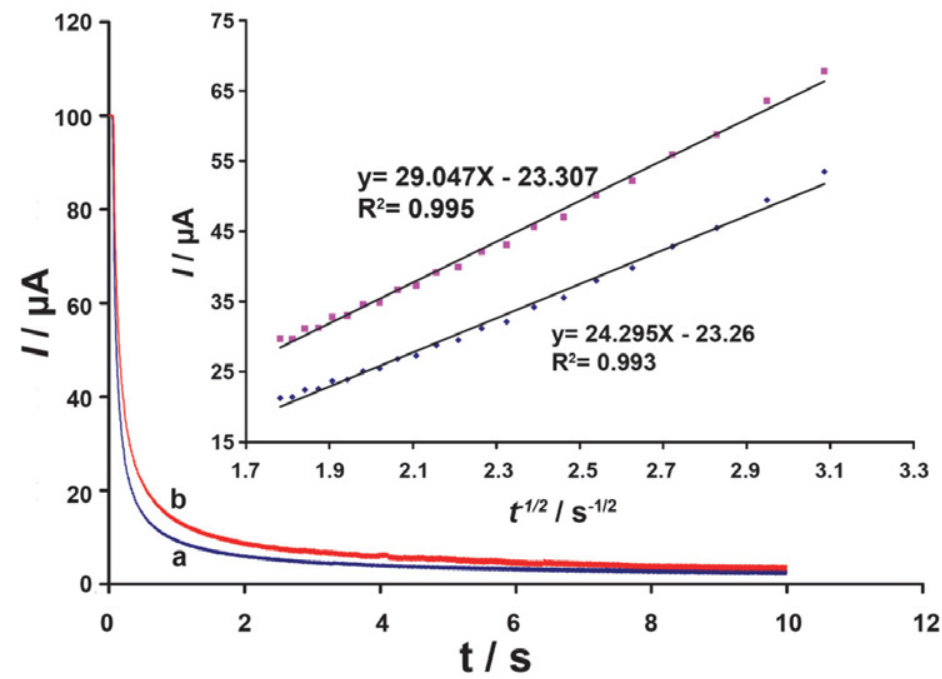

Figure 5. Chronoamperograms obtained at $\mathrm{CuO} / 1 \mathrm{E}^{2} \mathrm{MIBF}_{4} / \mathrm{CPE}$ in the presence of a) 300 ;and b) $500 \mu \mathrm{mol} \mathrm{L} \mathrm{L}^{-1}$ of 6 - $\mathrm{TG}$ in the buffer solution (pH 7.0). Inset: Cottrell's plot for the data from the chronoamperograms.

\section{Analytical Features}

In order to obtain calibration curve, square wave voltammograms (SWV) of solutions with different 6-TG concentrations were recorded at $\mathrm{CuO} / 1 \mathrm{E}_{3} \mathrm{MIBF}_{4} / \mathrm{CPE}$. Plot of net oxidation peak current versus concentration was linear in the range of $70 \mathrm{nmol} \mathrm{L}^{-1}$ to $520 \mu \mathrm{mol} \mathrm{L}^{-1} 6$-TG with the regression equation being $I_{p}(\mu \mathrm{A})=0.076 C_{6-T G}+0.174\left(\mathrm{R}^{2}\right.$ $=0.998)$ and detection limit of the method $20 \mathrm{nmol} \mathrm{L}^{-1}$ 6-TG $\left(3 S_{b} / m\right)$. This value of linear dynamic range or limit of detection compared with previous electrochemical sensor and results showed better analytical ability for proposed sensor (Table 1).

The relative standard deviation for square wave signals of $25 \mu \mathrm{mol} \mathrm{L}{ }^{-1} 6$-TG at the surface of $\mathrm{CuO} / 1 \mathrm{E} 3 \mathrm{MIBF}_{4} /$ $\mathrm{CPE}$ was $1.31 \%(\mathrm{n}=5)$, which confirmed excellent repeatability. The stability of $\mathrm{CuO} / 1 \mathrm{E}^{2} \mathrm{MIBF}_{4} / \mathrm{CPE}$ was checked by recorded square wave voltammograms of $25 \mu \mathrm{mol} \mathrm{L}-1$ 6-TG over a period of 25 days. Compared to its first oxidation current, only $2.9 \%$ deviation was recorded when $\mathrm{CuO} / 1 \mathrm{E} \mathrm{MIBF}_{4} / \mathrm{CPE}$ was used daily and stored in the laboratory. This suggests that $\mathrm{CuO} / 1 \mathrm{E}_{3} \mathrm{MIBF}_{4} / \mathrm{CPE}$ possesses long-term stability.

Table 2. Interference study for analysis of $50 \mu \mathrm{mol} \mathrm{L}{ }^{-1} 6-\mathrm{TG}$

\begin{tabular}{cc}
\hline Species & $\begin{array}{c}\text { Tolerance limits } \\
\text { (mole ratio) }\end{array}$ \\
\hline Glucose & 850 \\
$\mathrm{Na}^{+}, \mathrm{Br}^{-}, \mathrm{Cl}^{-}, \mathrm{K}^{+}$, Ascorbic acid & 550 \\
$\mathrm{Phenyl} \mathrm{alanine,} \mathrm{Glycine,} \mathrm{Methionine}_{\text {Starch }}$ & 400 \\
\hline
\end{tabular}

* After addition of $1 \mathrm{mmol} \mathrm{L}^{-1}$ ascorbic oxidize

Table 1. Characteristics of several electrochemical methods for determination of 6-TG

\begin{tabular}{|c|c|c|c|c|}
\hline Technique & $\begin{array}{l}\text { Electrochemical } \\
\text { Method }\end{array}$ & $\begin{array}{c}\text { Linear dynamic } \\
\text { range }\end{array}$ & $\begin{array}{l}\text { Detection } \\
\text { limit }\end{array}$ & Ref. \\
\hline $\begin{array}{l}\text { Study self-assembled monolayer } \\
\text { of } 6 \text {-TG on mercury electrode }\end{array}$ & cyclic and ac voltammetry & - & - & 6 \\
\hline DNA-modified gold electrode & $\begin{array}{l}\text { differential pulse stripping } \\
\text { voltammetry }\end{array}$ & $\begin{array}{l}2 \times 10^{-8}-8 \\
\times 10^{-7} \mathrm{~mol} \mathrm{~L}^{-1}\end{array}$ & $6 \times 10^{-9} \mathrm{~mol} \mathrm{~L}^{-1}$ & 7 \\
\hline $\begin{array}{l}\text { Complex formation and adsorption } \\
\text { on mercury electrode }\end{array}$ & cathodic adsorptive stripping & $0.15-180 \mathrm{nmol} \mathrm{L}^{-1}$ & $0.08 \mathrm{n} \mathrm{mol} \mathrm{L}^{-1}$ & 8 \\
\hline Electrocatalyst & differential pulse voltammetry & $\begin{array}{c}0.06-10 \mu \mathrm{mol} \mathrm{L}^{-1} \\
\text { and } 10-160 \mu \mathrm{mol} \mathrm{L}^{-1}\end{array}$ & $22 \mathrm{nmol} \mathrm{L}^{-1}$ & 50 \\
\hline $\begin{array}{l}\text { Study interaction between } \\
6 \text {-TG and DNA }\end{array}$ & $\begin{array}{l}\text { differential pulse voltammetry, } \\
\text { electrochemical impedance spectroscopy }\end{array}$ & - & - & 10 \\
\hline $\begin{array}{l}\text { Electrocatalyst and using } \\
\mathrm{ZnO}-\mathrm{CuO} \text { nanoplates }\end{array}$ & square wave voltammetric & 0.05 to $200 \mu \mathrm{mol} \mathrm{L}^{-1}$ & $25 \mathrm{n} \mathrm{mol} \mathrm{L}^{-1}$ & 11 \\
\hline $\begin{array}{l}\text { Modification of carbon paste with } \\
\mathrm{CuO} \text { nano particles and ionic liquid }\end{array}$ & square wave voltammetric & 0.07 to $520 \mu \mathrm{mol} \mathrm{L}^{-1}$ & $20 \mathrm{n} \mathrm{mol} \mathrm{L}-1$ & this wok \\
\hline
\end{tabular}


Table 3. Determination of 6-TG in real samples $(n=5)$

\begin{tabular}{|c|c|c|c|c|c|}
\hline Sample & $\left.\begin{array}{c}\text { Added } \\
(\mu \mathrm{mol} \mathrm{L} \\
-1\end{array}\right)$ & $\begin{array}{c}\text { Expected } \\
\left.(\mu \mathrm{mol} \mathrm{L})^{-1}\right)\end{array}$ & $\begin{array}{l}\text { Founded } \\
\left(\mu \mathrm{mol} \mathrm{L} \mathrm{L}^{-1}\right)\end{array}$ & $\begin{array}{c}\text { Recovery } \\
\%\end{array}$ & $\begin{array}{l}\text { Published method } \\
\left.(\mu \mathrm{mol} \mathrm{L})^{-1}\right)\end{array}$ \\
\hline \multirow[t]{2}{*}{ Tablet $^{*}$} & - & 5 & $4.92 \pm 0.35$ & 98.4 & $4.95 \pm 0.28$ \\
\hline & 10 & 15 & $15.63 \pm 0.75$ & 104.2 & $15.74 \pm 0.98$ \\
\hline Intravenous & - & - & $<$ Limit of detection & & \\
\hline solution $^{* *}$ & 20 & 20 & $20.75 \pm 0.82$ & 103.7 & $19.75 \pm 1.01$ \\
\hline
\end{tabular}

\pm Shows the standard deviation ${ }^{*}$ Kwality Pharmaceuticals limited, India. ${ }^{* *}$ Dextrose (3.33 \%), saline (0.3 \%), I.P.P.C.(Iranian Parenteral \& Pharmaceutical Co), Tehran, Iran.

To study the influence of various substances which may potentially interfere with the determination of 6-TG, the oxidation current of $50 \mu \mathrm{mol} \mathrm{L}{ }^{-1} 6$-TG was measured in the presence of different concentrations of interfering species and was compared with current that obtained from 6 -TG solution by acceptable error $\pm 5 \%$. The results are shown in Table 2 and confirm selectivity of $\mathrm{CuO} / 1 \mathrm{E}$ $3 \mathrm{MIBF}_{4} / \mathrm{CPE}$ for the analysis of 6-TG.

To study the application of $\mathrm{CuO} / 1 \mathrm{E}_{3} \mathrm{MIBF}_{4} / \mathrm{CPE}$ for analysis of 6-TG in real samples, the $\mathrm{CuO} / 1 \mathrm{E}^{2} \mathrm{MIBF}_{4} / \mathrm{CPE}$ was applied for the determination of 6-TG in tablets and intravenous dextrose-saline solutions (Table 3 ).

\section{Simultaneous Determination of 6-TG and 5-FU}

Square wave voltammogram of a solution containing 6-TG and 5-FU showed two distinguished peak currents.
In addition, changing the concentration of each one had no effect on the peak current of another one. Therefore, simultaneous determination was performed by simultaneously changing the concentrations of 6-TG and 5-FU and recording the SWVs. Figure 6 shows the calibration curves of 6-TG and 5-FU. The current sensitivities towards 6-TG in the presence and in the absence of 5-FU were found to be approximately equal which confirms that the oxidation processes of 6-TG and 5-FU at $\mathrm{CuO} / 1 \mathrm{E}^{2} \mathrm{MIBF}_{4} / \mathrm{CPE}$ are independent and simultaneous or independent measurements of two compounds are, therefore, possible without any interference.
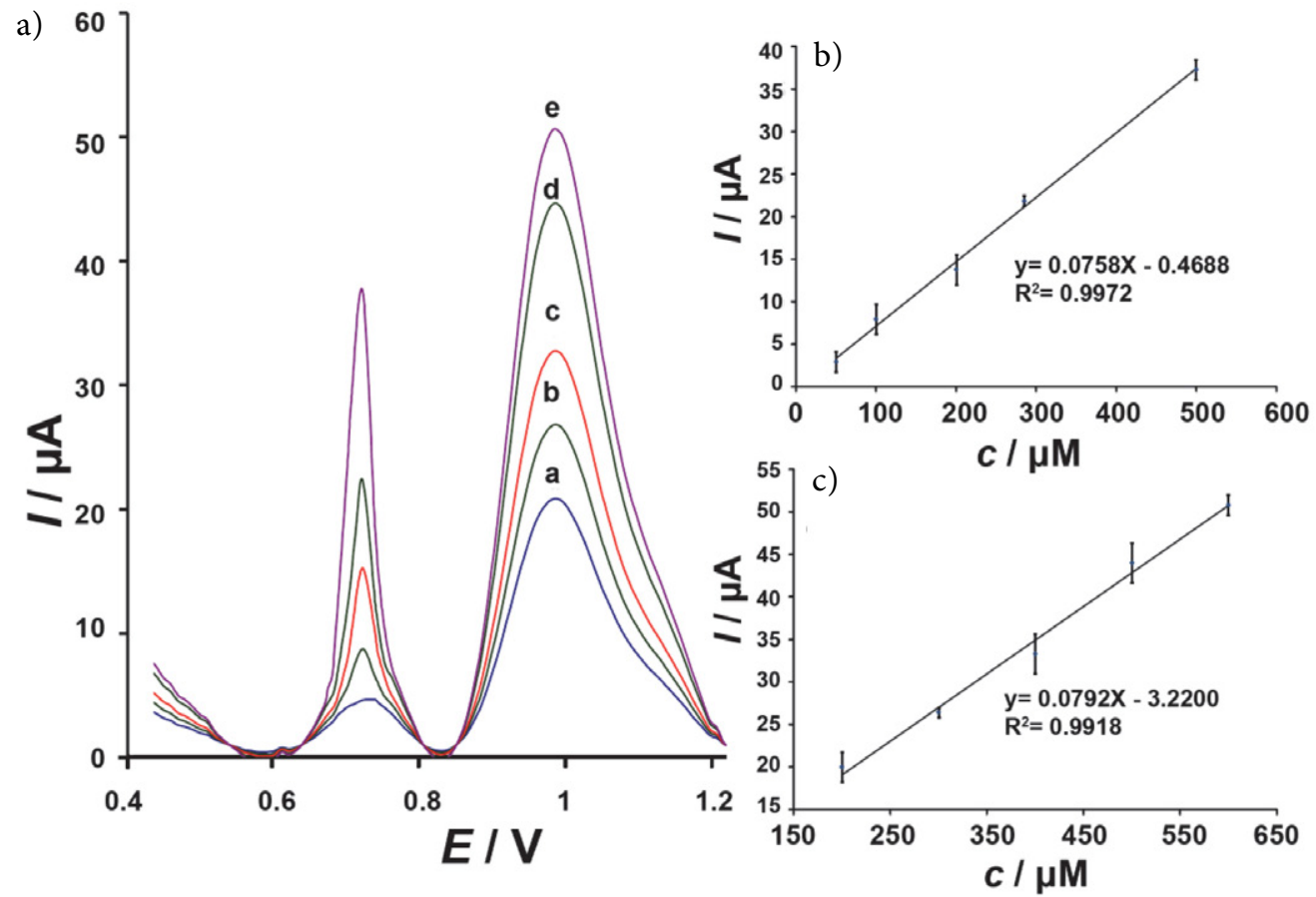

Figure 6. Inset; $\mathrm{SWVs}$ of $\mathrm{CuO} / 1 \mathrm{E} 3 \mathrm{MIBF}_{4} / \mathrm{CPE}$ ( $\mathrm{PBS}$ buffer, $\mathrm{pH}$ 7.0) containing different concentrations of 6-TG and 5-FU in $\mu \mathrm{mol} \mathrm{L}{ }^{-1}$. (a-e) $50+$ $200 ; 100+300 ; 200+400 ; 285+500$ and $500+600$, respectively. B) plot of the current as a function of 6-TG concentration. C) plot of the current as a function of 5 -FU concentration. 
of 5-FU, as two important anticancer drugs. The $\mathrm{CuO} / 1 \mathrm{E}-$ $3 \mathrm{MIBF}_{4} / \mathrm{CPE}$ showed good analytical ability for nanomolar determination of 6-TG. The $\mathrm{CuO} / 1 \mathrm{E}^{2} \mathrm{MIBF}_{4} / \mathrm{CPE}$ resolved overlapping signal of 6-TG and 5-FU at an optimum condition. The $\mathrm{CuO} / 1 \mathrm{E}_{3} \mathrm{MIBF}_{4} / \mathrm{CPE}$ was used for the analysis of 6-TG in real samples.

\section{Acknowledgements}

The author gratefully acknowledges Islamic Azad University, Falavarjan branch research council for support of this work.

\section{References}

1. J. K. Aronson, Book Meyler's side effects of drugs: the international encyclopedia of adverse drug reactions and interactions, Elsevier, 2015.

2. S. Enna and D. Bylund, Book xPharm: The Comprehensive Pharmacology Reference, Elsevier, 2008.

3. A. Attaran, Health Aff. 2004, 23, 155-166.

DOI:10.1377/hlthaff.23.3.155

4. J. G. Manjunatha, J. Surface Sci. Technol. 2018, 34, 74-80. DOI:10.18311/jsst/2018/15838

5. J. G. Manjunatha, Sens. Biosensing Res. 2017, 16, 79-84. DOI:10.1016/j.sbsr.2017.11.006

6. R. Madueno and T. Pineda, J. Electroanal. Chem. 2004, 565, 301-310. DOI:10.1016/j.jelechem.2003.10.024

7. S. F. Wang, F. Xie, R. F. Hu and H. C. Cai, Anal. Lett. 2006, 39, 1041-1052. DOI:10.1080/00032710600620328

8. A. A. Ensafi and R. Hajian, J. Brazil. Chem. Soc. 2008, 19, 405-412. DOI:10.1590/S0103-50532008000300006

9. H. Beitollahi, J.-B. Raoof and R. Hosseinzadeh, Anal. Sci. 2011, 27, 991-991. DOI:10.2116/analsci.27.991

10. E. Eksin, G. Congur, F. Mese and A. Erdem, J. Electroanal. Chem. 2014, 733, 33-38.

DOI:10.1016/j.jelechem.2014.08.012

11. H. Beitollahi, S. G. Ivari and M. Torkzadeh-Mahani, Mater. Sci. Eng., C 2016, 69, 128-133.

DOI:10.1016/j.msec.2016.06.064

12. N. S. Prinith and J. G. Manjunatha, Mater. Sci. Technol. Energy 2019, 2, 408-416. DOI:10.1016/j.mset.2019.05.004

13. J. G. Manjunatha, B. E. K. Swamy, G. P. Mamatha, C. Rarilb, L. N. Swamy and S. Fattepur, Materials Today: Proceedings 2018, 5, 22368-22375. DOI:10.1016/j.matpr.2018.06.604

14. C. Raril and J. G. Manjunatha, Anal. Bioanal. Electrochem. 2018, 10, 372-382.

15. G. Tigari, J. G. Manjunatha, C. Raril and N. Hareesha, Chemistry Select 2019, 4, 2168-2173. DOI:10.1002/slct.201803191

16. N. S. Prinith, J. G. Manjunatha and C. Raril, Anal. Bioanal. Electrochem. 2019, 11, 742-756.

17. J. G. Manjunatha, Open Chem Eng J. 2019, 13, 81-87. DOI:10.2174/1874123101913010081

18. S. Cheraghi, M. A. Taher and H. Karimi-Maleh, J. Food Compos. Anal. 2017, 62, 254-259.

DOI:10.1016/j.jfca.2017.06.006
19. B. J. Sanghavi, G. Hirsch, S. P. Karna and A. K. Srivastava, Anal. Chim. Acta 2012, 733, 37-45.

DOI:10.1016/j.aca.2012.05.029

20. J. G. Manjuntha and G. K. Jayaprakash, Eurasian J. Anal. Chem. 2019, 14, 1-11.

21. H. Karimi-Maleh and O. A. Arotiba, J. Colloid Interface Sci. 2020, 560, 208-212. DOI:10.1016/j.jcis.2019.10.007

22. H. Karimi-Maleh, F. Karimi, M. Alizadeh and A. L. Sanati, Chem. Rec. 2020. DOI:10.1002/tcr.201900092

23. H. Karimi-Maleh, C. T. Fakude, N. Mabuba, G. M. Peleyeju and O. A. Arotiba, J. Colloid Interface Sci. 2019, 554, 603-610. DOI:10.1016/j.jcis.2019.07.047

24. F. Tahernejad-Javazmi, M. Shabani-Nooshabadi and H. Karimi-Maleh, Composites Part B: Engineering 2019, 172, 666670. DOI:10.1016/j.compositesb.2019.05.065

25. A. Khodadadi, E. Faghih-Mirzaei, H. Karimi-Maleh, A. Abbaspourrad, S. Agarwal and V. K. Gupta, Sens. Actuators, B 2019, 284, 568-574. DOI:10.1016/j.snb.2018.12.164

26. Z. Shamsadin-Azad, M. A. Taher, S. Cheraghi and H. Karimi-Maleh, J. Food Meas. Charact. 2019, 13, 1781-1787. DOI:10.1007/s11694-019-00096-6

27. H. Karimi-Maleh, M. Shafieizadeh, M. A. Taher, F. Opoku, E. M. Kiarii, P. P. Govender, S. Ranjbari, M. Rezapour and Y. Orooji, J. Mol. Liq. 2020. DOI:10.1016/j.molliq.2019.112040

28. H. Karimi-Maleh, M. Sheikhshoaie, I. Sheikhshoaie, M. Ranjbar, J. Alizadeh, N. W. Maxakato and A. Abbaspourrad, New J. Chem. 2019, 43, 2362-2367. DOI:10.1039/C8NJ05581E

29. M. Miraki, H. Karimi-Maleh, M. A. Taher, S. Cheraghi, F. Karimi, S. Agarwal and V. K. Gupta, J. Mol. Liq. 2019, 278, 672-676. DOI:10.1016/j.molliq.2019.01.081

30. S. Malekmohammadi, H. Hadadzadeh, S. Rezakhani and Z. Amirghofran, ACS Biomater. Sci. Eng. 2019, 5, 4405-4415. DOI:10.1021/acsbiomaterials.9b00237

31. Y. Akbarian, M. Shabani-Nooshabadi and H. Karimi-Maleh, Sens. Actuators, B 2018, 273, 228-233.

DOI:10.1016/j.snb.2018.06.049

32. M. Fouladgar and S. Mohammadzadeh, Anal. Lett. 2014, 47, 763-777. DOI:10.1080/00032719.2013.855782

33. M. L. Yola and N. Atar, Electrochim. Acta 2014, 119, 24-31. DOI:10.1016/j.electacta.2013.12.028

34. L. Shang, F. Zhao and B. Zeng, Food Chem. 2014, 151, 53-57. DOI:10.1016/j.foodchem.2013.11.044

35. C. Jianrong, M. Yuqing, H. Nongyue, W. Xiaohua and L. Sijiao, Biotechnol. Adv. 2004, 22, 505-518.

DOI:10.1016/j.biotechadv.2004.03.004

36. M. E. Grigore, E. R. Biscu, A. M. Holban, M. C. Gestal and A. M. Grumezescu, Pharmaceuticals 2016, 76, 75-89.

DOI: $10.3390 / \mathrm{ph} 9040075$

37. A. El-Trass, H. ElShamy, I. El-Mehasseb and M. El-Kemary, Appl. Surf. Sci. 2012, 258, 2997-3001.

DOI:10.1016/j.apsusc.2011.11.025

38. W. Sun, M. Yang and K. Jiao, Anal. Bioanal. Chem. 2007, 389, 1283-1291. DOI:10.1007/s00216-007-1518-2

39. H. Khani, M. K. Rofouei, P. Arab, V. K. Gupta and Z. Vafaei, J. Hazard. Mater. 2010, 183, 402-409.

DOI:10.1016/j.jhazmat.2010.07.039 
40. M. Fouladgar, Measurement 2016, 86, 141-147. DOI:10.1016/j.measurement.2016.02.057

41. Y. Zhang and J. B. Zheng, Electrochim. Acta 2007, 52, 72107216. DOI:10.1016/j.electacta.2007.05.039

42. W. Sun, Y. Li, M. Yang, S. Liu and K. Jiao, Electrochem. Commun. 2008, 10, 298-301.

DOI:10.1016/j.elecom.2007.12.012

43. S. Negahban, M. Fouladgar and G. Amiri, J. Taiwan Inst. Chem. Eng. 2017, 78, 51-55. DOI:10.1016/j.jtice.2017.05.032

44. M. Ashjari, H. Karimi-Maleh, F. Ahmadpour, M. Shabani-Nooshabadi, A. Sadrnia and M. A. Khalilzadeh, J. Taiwan Inst. Chem. Eng. 2017, 80, 989-996.

DOI:10.1016/j.jtice.2017.08.046
45. M. Fouladgar, J. Electrochem. Soc. 2016, 163, B38-B42. DOI:10.1149/2.0611603jes

46. M. Fouladgar, Sens. Actuators, B 2016, 230, 456-462. DOI:10.1016/j.snb.2016.02.094

47. M. Shamsipur, A. A. M. Beigi, M. Teymouri, S. M. Pourmortazavi and M. Irandoust, J. Mol. Liq. 2010, 157, 43-50. DOI:10.1016/j.molliq.2010.08.005

48. J. Fuller, R. T. Carlin and R. A. Osteryoung, J. Electrochem. Soc. 1997, 144, 3881-3886. DOI:10.1149/1.1838106

49. P. Kraske, J. Electroanal. Chem. Interfacial Electrochem. 1986, 207, 101-116. DOI:10.1016/0022-0728(86)87065-6

50. H. Karimi-Maleh, M. R. Ganjali, P. Norouzi and A. Bananezhad, Mater. Sci. Eng., C 2017, 3, 472-477.

DOI:10.1016/j.msec.2016.12.094

\section{Povzetek}

Analiza protirakavih zdravil je zelo pomembna in potrebna za njihovo pravilno uporabo v človeškem telesu. Preučevali smo elektrokemijsko obnašanje 6-tioguanina (6-TG) z uporabo elektrode iz ogljikove paste, modificirane z 1-etil-3-metilimidazolijevim tetrafluoroboratom (ionska tekočina) (1E3MIBF4) in nanodelci $\mathrm{CuO}$ (CuO/1E3MIBF4/CPE). Uporaba square wave voltametrije je pokazala linearno zvezo med celotnim anodnim tokom in koncentracijo 6-TG v območju od $70 \mathrm{nmol} \mathrm{L}{ }^{-1}$ do $520 \mu \mathrm{mol} \mathrm{L}{ }^{-1}$ 6-TG z mejo zaznave $20 \mathrm{nmol} \mathrm{L}-1$ 6-TG. Predlagana modificirana elektroda je imela odlično ponovljivost $(\mathrm{RSD}=1,31 \%, \mathrm{n}=5)$ in dolgoročno stabilnost (2,9\% odstopanje $\mathrm{v} 25 \mathrm{dneh})$. Ugotovljeno je bilo, da je koeficient difuzije 6-TG na CuO / 1E3MIBF4/CPE 1,54 × $10^{-5} \mathrm{~cm}^{2} \mathrm{~s}^{-1}$. CuO/1E3MIBF4/CPE je bil uspešno uporabljen za določanje 6-TG v realnih vzorcih. Poleg tega je mogoče anodne vrhove 6-TG in fluorouracila (5-FU) v njuni mešanici dobro ločiti $\mathrm{z}$ uporabo $\mathrm{CuO} / 1 \mathrm{E} 3 \mathrm{MIBF} 4 / \mathrm{CPE}$ in ju preučevati istočasno.

Except when otherwise noted, articles in this journal are published under the terms and conditions of the Creative Commons Attribution 4.0 International License 